\title{
Changes in Seal Habitat Use of Nearshore Waters around Newfoundland and Southern Labrador: Implications for Potential Predation on Salmon
}

\author{
Crystal C. Lenky*,1 and Becky Sjare ${ }^{2}$ \\ ${ }^{1}$ Department of Biology, Memorial University, St. John's, Newfoundland, Canada A1B $3 X 9$ \\ ${ }^{2}$ Department of Fisheries and Oceans, 80 East White Hills Road, P.O. Box 5667, St. John's, Newfoundland, Canada \\ A1C $5 X 1$
}

\begin{abstract}
The reasons for the decline in some Atlantic salmon (Salmo salar) stocks in Newfoundland and southern Labrador are not fully understood, but many resource users consider predation by seals in rivers and nearshore waters to be a contributing factor. To address these concerns, local ecological knowledge (LEK) interviews with resource users ( $\mathrm{n}=$ 57) were conducted at 29 rivers throughout the Province to evaluate the potential for seal predation over a 25 -year period when major changes were occurring in the structure of the Northwest Atlantic ecosystem. Based on LEK, eight rivers frequented by harp seals (Pagophilus groenlandicus), nine by harbor seals (Phoca vitulina) and three by gray seals (Halichoerus grypus) were evaluated as having a high potential for predation. According to respondents, the relative abundance of seals at these rivers started increasing in the mid 1990s or 2000, depending on the seal species involved. Variation in potential predation from river to river was attributed to a number of factors including the distribution of forage fish, variability in local ice conditions, the geography of the river and ecology of seal species frequenting the area. Resource users provided a useful and, in many cases, new perspective on the spatial and temporal overlap of seals, particularly harp seals, capelin (Mallotus villosus) and salmon in some areas. However, quantitative seal diet information and knowledge of seal-salmon relative abundances are required to assess the biological significance of these results from a salmon conservation perspective.
\end{abstract}

Keywords: Harp seal, local ecological knowledge, predation, Atlantic salmon.

\section{INTRODUCTION}

Atlantic salmon (Salmo salar) have a well-documented history of commercial, recreational and subsistence exploitation by aboriginal and non-aboriginal communities in Newfoundland and coastal Labrador [1, 2]. Prior to the mid 1980s, Newfoundland and Labrador salmon populations were considered healthy. However, their abundance declined to such low levels that moratoria were placed on the Newfoundland commercial salmon fishery in 1992 followed by the Labrador fishery in 1997 [3]. River closures and stricter recreational fishing restrictions have been in place since that time. Reasons for the decline in salmon abundance are not fully understood, but over-fishing, habitat loss, environmental conditions, mortality at sea, and seal and seabird predation are among the possible causes [4].

Evaluating the importance of seal predation on salmon is difficult given how little is known about seal diet, habitat use and distribution around Newfoundland and Labrador during salmon migrations. In the case of harp seals (Pagophilus groenlandicus), diet studies have primarily documented the late autumn and winter feeding periods when seals are most abundant in the region; there was no evidence of salmon consumption at this time [5-7]. However, relatively few spring and summer samples have been collected from

*Address correspondence to this author at the Gateway Antarctica, University of Canterbury, Private Bag 4800, Christchurch New Zealand 8140; Tel: +64 3 364-2987 ext. 4982; Fax: +64 3 364-2197;

E-mail: crystal.lenky@pg.canterbury.ac.nz nearshore waters when there might be a higher probability of detecting harp seal predation on salmon given the spatial proximity of the two species [8]. There is no evidence of salmon in the limited diet information available for harbor seals (Phoca vitulina; [9]) and only two documented occurrences for gray seals (Halichoerus grypus; [10, 11]). However, predation on Pacific [12-14] and northeast Atlantic [15] salmon by both these seal species has been well documented. Little is known about the diets of ringed (Pusa hispida) and bearded seals (Erignathus barbatus) frequenting Newfoundland and Labrador waters.

During the same period that salmon populations were declining in Newfoundland and Labrador, major changes were occurring in the structure of the Northwest Atlantic ecosystem [16-18]. Colder than normal water temperatures from the late 1980s to the mid 1990s are thought to have affected the biology, biomass and distribution patterns of many species including schooling forage fish (e.g. capelin (Mallotus villosus), Arctic cod (Boreogadus saida)) and harp seals [19-22]. Capelin and Arctic cod are important prey for seals in the northwest Atlantic, especially the harp seal [23]. During the early 1990s, capelin populations declined in offshore areas around Newfoundland, and their distribution shifted east to occupy areas on the Flemish Cap and south towards the Scotian Shelf $[19,24]$. In nearshore waters, capelin were smaller compared to the 1980 s, beach spawning was delayed by one to two months, or in some locations did not occur at all $[18,24]$. At the same time, Arctic cod distribution shifted south from Arctic and Labrador waters 
into nearshore areas of Newfoundland [25] and replaced capelin as the dominant prey item for harp seals in coastal areas along northeastern Newfoundland during the 1990s [5, 26].

Concurrent with these changes, there were many anecdotal reports from resource users to the Department of Fisheries and Oceans (DFO) noting both increased numbers of seals frequenting river and nearshore habitats and the presence of seals at unusual times of the year. Preliminary follow up investigations by DFO personnel indicated that these were primarily harp seal sightings (Wayne Penney, personal communication, 2004 ${ }^{1}$ ). These observations suggested a change in seasonal migration patterns and distribution for a segment of the population. Traditionally, harp seals migrate south along the Labrador coast ahead of locally forming pack ice, reaching the Strait of Belle Isle in November or December, and then disperse into the Gulf of St. Lawrence and on to the Grand Banks to continue feeding until early March. Adult harp seals begin their northern migration in May to summer feeding grounds in the Canadian Arctic, with pups following shortly after [27]. During the 1990s it appeared some harp seals deviated from this seasonal pattern by moving into nearshore waters earlier in the fall and staying later into summer.

There were relatively few reports by resource users to DFO of major changes in the distribution and relative abundance of harbor or gray seals. In Newfoundland and Labrador, harbor seals have historically used river and nearshore habitats and are thought to be relatively sedentary with foraging activity occurring in the vicinity of haul-out sites [9, 28]. Gray seals over-wintering and breeding in the southern Gulf of St. Lawrence and on Sable Island off Nova Scotia disperse into Newfoundland and Labrador waters during the summer and fall [29]. The population has increased significantly in the Gulf since $1970[30,31]$ and there have been anecdotal reports of increased sighting in some areas of Newfoundland, but little evidence of major changes in their distribution and habitat use. Nothing is known about the possible changes experienced by the remaining seal species frequenting coastal Newfoundland and Labrador waters.

Although oceanographic conditions have warmed since 1996 [32], capelin distribution and spawning times have remained variable or delayed [18], the use of rivers and nearshore waters by harp seals during the late spring and summer continued to remain high until at least 2007 and there has been no sustained recovery of some salmon stocks [33]. Documenting the response of a single marine species to large-scale ecosystem change and oceanographic perturbations is difficult; attempting to understand multispecies interactions is an even greater challenge. This is particularly true when the feeding habits of harp seals, a highly mobile and adaptive apex predator, are a research focus. The task is further complicated because knowledge of climate-related changes in the distribution, relative abundance and spawning behavior of key forage fish species in many parts of Newfoundland and Labrador is fragmentary.

${ }^{1}$ Wayne Penny, Department of Fisheries and Oceans, P.O. Box 5667, St. John's NL, A1C 5X1, Canada.
In this study, local ecological knowledge (LEK) was used to document the seasonal presence, habitat use and relative abundance of seals and key forage fish species in selected salmon rivers and nearshore waters over a 25 year time period when the Northwest Atlantic marine ecosystem was undergoing significant change. This approach was adopted because resource users often acquire long-term ecological knowledge about the species they harvest and interact with as well as knowledge of changes in the marine environment when data from other sources are limited or not available [34-36]. This information can be useful in complementing Western science and is increasingly being incorporated into environmental assessment and resource management studies [34, 37-39].

The specific objectives of this study were to first use ecological knowledge to document any changes in the following: 1) the distribution, habitat use, and migration patterns of seals, 2) the presence and spawning times of forage fish that are important to both seals (particularly harp seals) and salmon, and 3) the occurrence of seal-salmon interactions. Then, using these data, evaluate whether there has been a change in the potential for seal predation on smolt or adult salmon based on the spatial and temporal overlap of these species on a river specific basis. The overall goal of this study was to use LEK to prioritize and provide direction for future research on rivers that we identified as having high potential for seal predation on salmon. Although some aspects of this research focused more on harp seals, information on other seal species in Newfoundland and southern Labrador waters is reported as well.

\section{MATERIALS AND METHODOLOGY}

We conducted interviews between March 2004 and August 2006 with 57 resource users regarding their knowledge of 29 salmon rivers in Newfoundland and southern Labrador. Nineteen rivers were located in Newfoundland (northeast coast $n=3$; south coast $n=5$; west coast $n=11$ ) and 10 in southern Labrador (Fig. 1). They were chosen because most are regulated, or scheduled salmon rivers, and in many cases have been the focus for salmon assessment research and management initiatives by DFO in the past. The resource users interviewed included active and retired inshore fishermen, recreational salmon anglers and seal hunters, as well as fishery officers and aboriginal river guardians. Some of the respondents were recommended by DFO research personnel based on their expertise and contributions to previous departmental research programs in their community; the others were selected using a snowball sampling technique [34]. This is a method where people within a community who have the most knowledge on a particular topic are identified by their peers. Respondents were then selected based on the number of recommendations they received from local community members; those with two or more recommendations were contacted for an interview. This ensured that people interviewed were knowledgeable, had long-term experience in the fishery and were interested in contributing to a research project.

Interview protocol followed a semi-directive procedure [40] where a set list of questions was used, but respondents were also given the opportunity to bring up topics they felt 


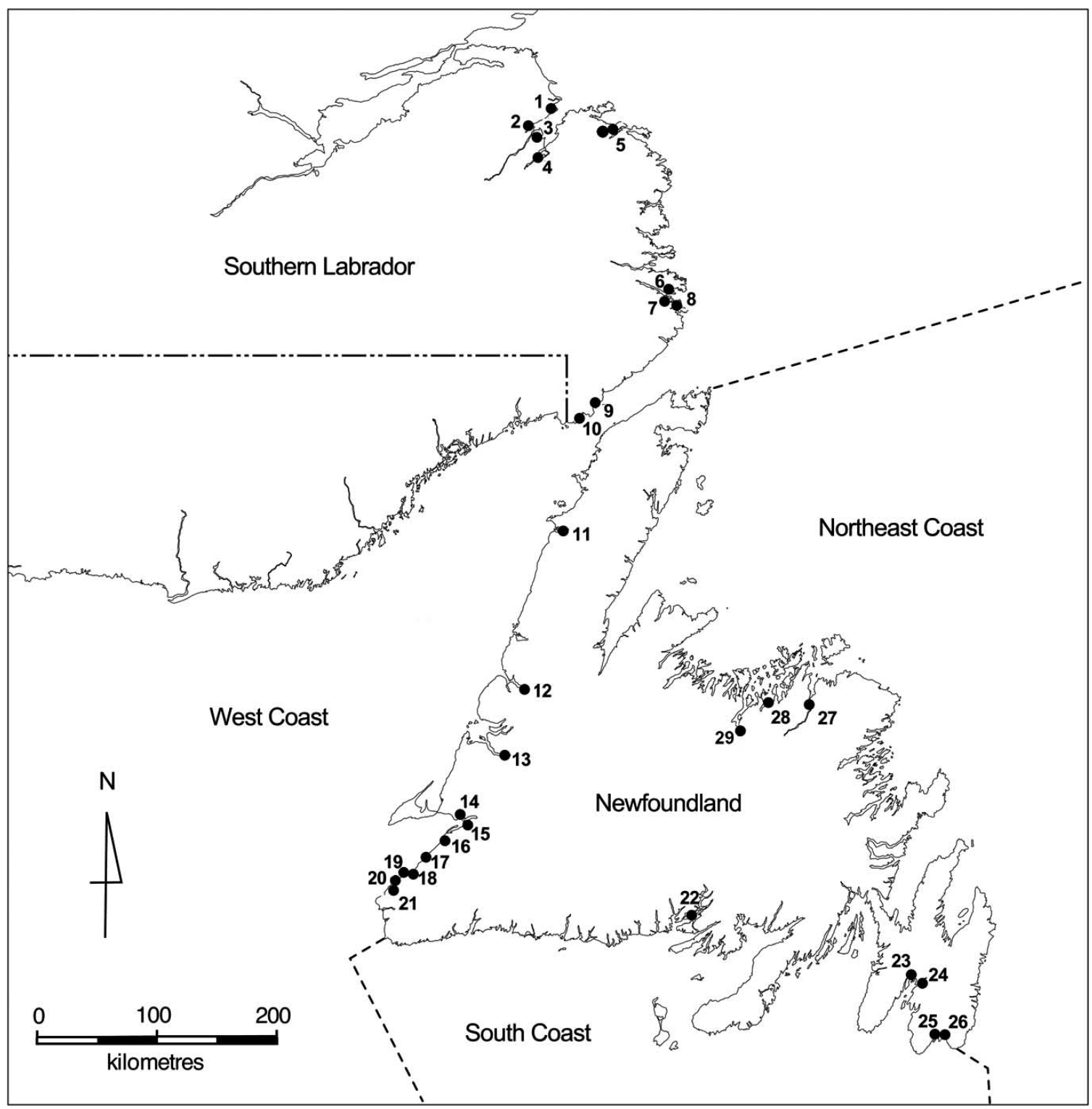

Fig. (1). Map of Newfoundland and southern Labrador rivers where LEK interviews were conducted. (River names in Table 1).

were relevant to the research. At the start of each interview, a marine mammal identification guide was shown to identify seal species and clarify common name usage between the interviewer and respondent. Interviews of approximately one hour were recorded with the permission of the participant and later transcribed. Locational information, including seal migration routes, seal haul-out and foraging sites, forage fish spawning areas (including capelin beaches), important physical characteristics of the river or estuary, and areas of local ice coverage were marked on 1:50,000 and 1:250,000 topographic maps. In most cases, three or more individuals with extensive knowledge of their area were interviewed for each river while some were interviewed for a group of rivers (e.g. St. Lewis Sound and St. George's Bay rivers). Followup interviews, by telephone or in-person, were conducted to re-confirm information.

The interviews focused on three time periods: 1980-1989 (historic), 1990-1999 (recent past), and 2000-2005 (present). The questions were organized so that respondents could identify with pivotal dates relevant to the three time periods (e.g. the pre Atlantic cod (Gadus morhua) moratorium years, the early cod moratorium years and the salmon moratorium years). The interview questions were designed to: 1) examine changes in the distribution, relative abundance, and habitat use of seals in rivers, at the river mouth and in nearshore waters (bays, headlands and waters within $3 \mathrm{~km}$ of an exposed shoreline); 2) document changes in the timing and seasonal presence of forage fish; and 3) provide a general overview of any observed changes in the local marine environment in relation to anthropogenic or large scale ecosystem changes that occurred during the study period. For questions relating to the occurrence and relative abundance of seals in a coastal area, respondents were asked to comment on whether seals were observed daily (common), once or twice per week (occasional), less than once per week (rare), or never observed during smolt or adult salmon runs. They were also asked whether seals were single animals, small sculls of 3-15, or larger sculls of $>15$. For questions focusing on forage fish, respondents were asked 
Table 1. Changes in the Occurrence of Harp Seals (Pg), Harbor Seals (Pv) and Gray Seals (Hg) Frequenting Rivers and Estuaries Around Newfoundland and Southern Labrador During Smolt (S) or Adult (A) Salmon Runs Across the Study Period. Seals Never Observed (-); Observed < Once Per Week (+); Observed Once Or Twice Per Week (++); Daily (+++). Shaded Cells Indicate Rivers That May Currently Have a High Potential for Seal Predation. Refer to Fig. (1) for Location of Rivers

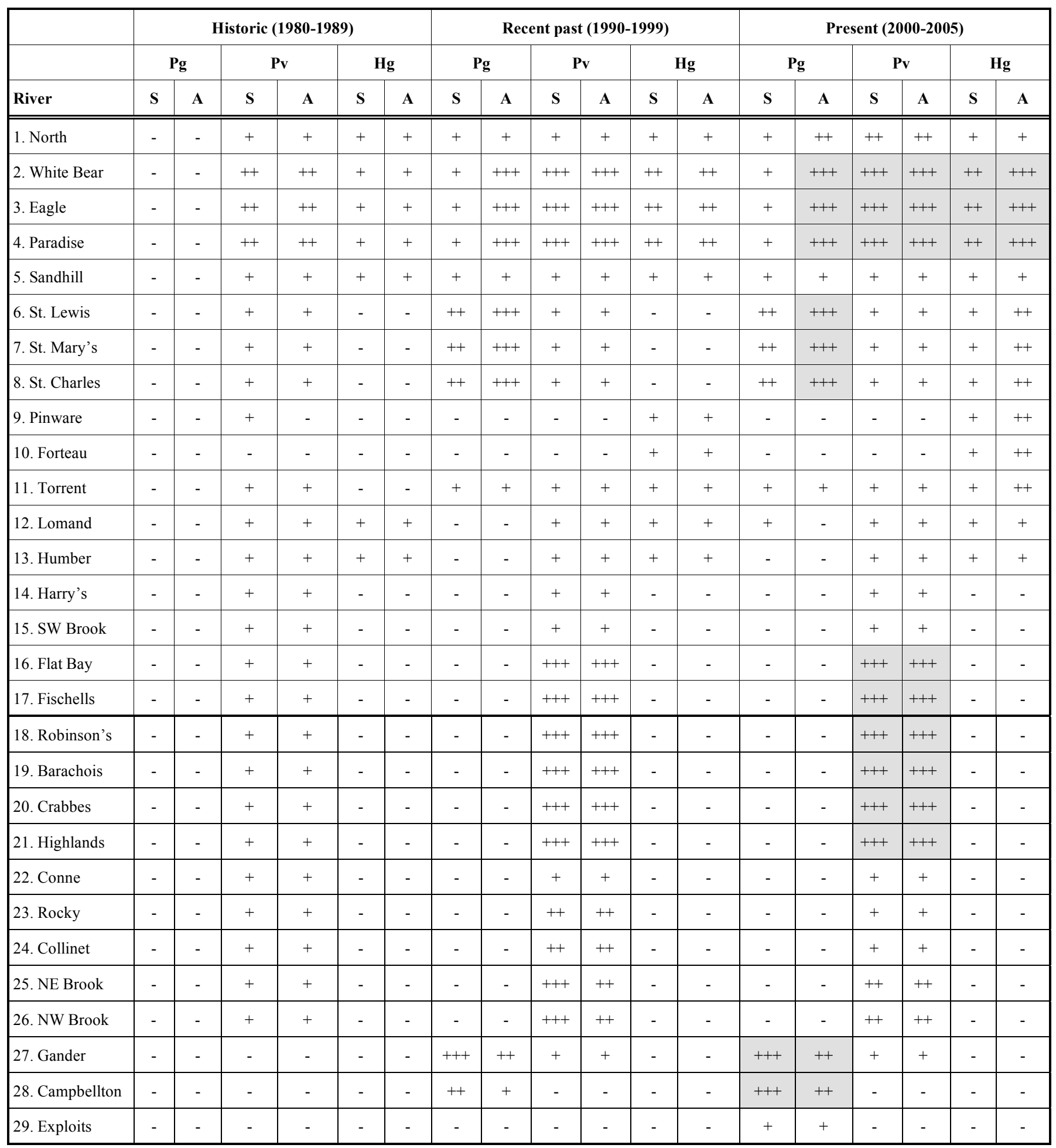

about spawning times, spawning areas and trends in relative abundance.

Documenting direct evidence of seal predation on salmon is difficult given the mobility and foraging behavior of the predator and the aquatic habitat of the prey. For the purposes of this study, potential seal predation on salmon refers to the opportunity for a predation event or predator-prey interaction to occur given that there is spatial and temporal overlap of 
predators (seals) and prey (salmon). Seal-salmon interactions were defined as direct if a seal(s) was observed chasing or consuming salmon or when distinctive claw or tooth marks were observed on salmon. Indirect seal-salmon interactions included scenarios when seals were present at the same time in the vicinity of salmon migration corridors, and when there was evidence that seals were removing salmon from fishing nets (e.g. holes in net).

We evaluated potential seal predation on salmon at each river using the following three criteria: 1) the occurrence and relative abundance of seals during the smolt or adult salmon run, 2) observations of either direct or indirect seal-salmon interactions, and 3) ecological or physical habitat characteristics that may attract seals to the area as well as increase the susceptibility of salmon to predation (e.g. warm water temperatures and low flow rates, light spring ice conditions, or physical river features that enhance salmon aggregation). A qualitative examination of the criteria across the three time periods of the study provided a perspective on the direction, magnitude and general timing of changes in potential seal predation at each river. Based on these criteria, we categorized each river as having a high, moderate or low potential for seal predation on smolt or adult salmon based on the most recent time period, 2000-2005. A river was categorized as having high predation potential when seals were commonly sighted during a salmon run, resource users had direct or indirect observations of seal-salmon interactions, and there was evidence that an ecological or physical habitat feature could increase the susceptibility of salmon to seal predation. Rivers were categorized has having moderate potential when seals were occasionally sighted during a salmon run, there were observations of indirect sealsalmon interactions, and there was only limited evidence that an ecological or physical habitat feature could increase the susceptibility of salmon to seal predation. In cases where a river could be categorized as having a high or moderate potential, the occurrence of indirect interactions was considered to be the most relevant factor. We categorized a river as having low potential when seals were rarely or never observed during a salmon run and there was no evidence of seal-salmon interactions.

\section{RESULTS}

\section{General Overview}

The seasonal occupation of rivers and nearshore habitats by seals during salmon migrations varied both by seal

Table 2. Seal-Salmon Interactions in Nearshore Waters and Rivers of Newfoundland and Southern Labrador as Reported by Resource Users. A (+) Indicates a Direct or Indirect Seal-Salmon Interaction and (-) no Interaction with Harp (Pg), Harbor (Pv) or Gray (Hg) Seals. For Rivers not Listed, there were no Reported Interactions

\begin{tabular}{|c|c|c|c|c|}
\hline River & \multicolumn{3}{|c|}{ Seal species } & Type of Interaction \\
\hline 2. White Bear & + & + & + & Pg feeding on capelin along headlands during adult migrations; $\mathrm{Pv}$ and $\mathrm{Hg}$ damage to salmon nets \\
\hline 3. Eagle & + & + & + & Pg feeding on capelin along headlands during adult migrations; $\mathrm{Pv}$ and $\mathrm{Hg}$ damage to salmon nets \\
\hline 6. St. Lewis & + & - & + & Pg and capelin overlap in St. Lewis Sound during smolt/adult migrations; Hg damage to salmon nets \\
\hline 7. St. Mary's & + & + & + & $\mathrm{Pg}$ and capelin overlap in St. Lewis Sound; $\mathrm{Pv}$ observed at river mouth; $\mathrm{Hg}$ damage to salmon nets \\
\hline 8. St. Charles & + & - & + & Pg and capelin overlap in St. Lewis Sound; Hg damage to salmon nets \\
\hline 9. Pinware & - & - & + & Observed at herring nets adjacent to river mouth and hauled out at river mouth during adult migrations \\
\hline 16. Flat Bay & - & + & - & Hauled out near river mouth; chasing salmon in the river \\
\hline 17. Fischells & - & + & - & Present near river mouth during smolt and adult migrations \\
\hline 18. Robinsons & - & + & - & Present near river mouth during smolt and adult migrations \\
\hline 19. Barachois & - & + & - & Present near river mouth during smolt and adult migrations \\
\hline 20. Crabbes & - & + & - & Present near river mouth during smolt and adult migrations \\
\hline 21. Highlands & - & + & - & Present near river mouth during smolt and adult migrations \\
\hline 25. NE Brook & - & + & - & Present near river mouth during smolt and adult migrations \\
\hline
\end{tabular}


species and geography (Table 1). Potential harp seal predation on salmon was evaluated to be high for $8 / 16$ rivers on the northeast coast of Newfoundland and southern coast of Labrador (Fig. 1: locations 1-8, 11-12). Rivers on the west coast located in St. George's Bay, and those inland on the southern coast of Newfoundland were more susceptible to potential harbor seal predation with 9/24 rivers being considered to have high predation potential. Potential gray seal predation on salmon was considered to be high at $3 / 11$ rivers in southern Labrador during the adult run. For these rivers, potential predation was evaluated for each species individually. Bearded, hooded (Cystophora cristata) and ringed seals were observed near several rivers around the Province but were rarely or never observed during salmon runs.

Observations of direct and indirect interactions between seals and salmon varied among rivers; direct observations of predation were rare (Table 2). The biological or physical habitat features most commonly reported to be important in determining the susceptibility of salmon to seal predation could be grouped into three categories: 1) factors that appeared to attract more seals into an area (e.g. alternative prey sources, light spring ice conditions), 2) habitat features that compromised the anti-predator evasive tactics of salmon (e.g. warm water temperatures, low river flow rates), and 3) natural or man-made habitat features that caused salmon to aggregate, making them more accessible to seals (e.g. waterfalls, bridges and causeways) (Table 3). Details of the interviews are summarized below beginning with rivers that were reported to have harp seal-salmon interactions followed by those with harbor and gray seal interactions.

\section{Harp Seals}

Prior to 1990, harp seals were rarely observed by resource users during salmon runs in nearshore waters along northeastern Newfoundland and southern Labrador. In the recent past (1990s), a notable increase in their occurrence and relative abundance had been observed; this increase has continued through the present time period. Most evidence of indirect interactions involving harp seals occurred when large sculls were observed foraging (usually for capelin) in the vicinity of salmon migration pathways near the headlands of a river mouth.

\section{Southern Labrador}

Respondents from St. Lewis Sound (5/5; those respondents in agreement) and Sandwich Bay (7/7) indicated that the relative abundance and residency time of harp seals started to increase in the mid to late 1990 s respectively (Table 1; Fig. 1: locations 2-4 and 6-8). Historically, harp seals would migrate north by the end of May or early June passing by these areas, but in the recent past, respondents observed sculls ranging from 15 to hundreds of animals with varying age class composition in July and August. During the present time period, the occurrence and activity of seals in St. Lewis Sound appeared to be influenced by the presence of capelin in the area. According to respondents, capelin had largely disappeared from the area by the early 1990s, but started to return in 2001 and 2002. However, they noted migration and spawning times were still highly variable compared to the 1980s. Capelin traditionally spawned in late June but now this activity occurs anytime from mid July up to November (4/5 respondents). The scenario was similar for Sandwich Bay during the present time period with $4 / 7$ respondents having observed seals foraging on schools of capelin along the headlands at the entrance of the Bay, an area important for migrating adult salmon, during July and early August. The relative abundance of capelin in the Bay was considered to be low throughout most of the study period, but improved in 2002 even though migration and spawning times remained delayed (7/7 respondents).

The changes in capelin spawning times and the increased residency time of harp seals appears to have resulted in an overlap with adult salmon migrating into the St. Lewis, St. Mary's and St. Charles. The presence of seals during this time period also overlaps with the subsistence salmon fishery for aboriginal and Labrador residents. When the subsistence fishery started in 2000, all respondents reported problems with harp seals at their nets. In the case of Sandwich Bay, changes in capelin spawning times and the increased residency time of harp seals may have resulted in an overlap with adult salmon migrating into the Bay enroute to the White Bear, Eagle and Paradise rivers. However, respondents noted that seals rarely frequented the inner reaches of Sandwich Bay during this time. None of the respondents from St. Lewis Sound or Sandwich Bay were able to comment on what harp seals may have been feeding on, other than capelin, during the recent past when capelin relative abundance was thought to be relatively low in both areas. Respondents provided no evidence of an increase in the spatial or temporal overlap of harp seals and salmon on the Forteau Brook or Pinware River in southern Labrador (Table 1; Fig. 1: locations 9-10).

\section{Newfoundland}

At Campbellton River, 4/4 respondents noted an increase in the relative abundance and residency time of harp seals in Indian Arm Bay starting in the late 1990s (Table 1; Fig. 1: location 28). Historically, the majority of seals left the area by early May. Since 2000, all respondents have observed beaters (young of the year) and adult seals until the end of June with occasional observations in July and August. Single or small sculls of 2-3 beaters were most commonly observed but sculls of 5-15 adults also frequented the area. Capelin spawns in the bay, but two respondents noted that its relative abundance has declined over the last 5 years, one over the last ten years, and one commented that capelin has been gradually decreasing over the last 20 years. However all agreed that since the late 1990s spawning times are delayed by 1 to 2 months (July and August) and in some years does not occur at all on certain beaches. The increased residency time of seals overlaps with the migrations of smolt and kelt (recently spawned) salmon, a concurrent run of smelt (Osmerus mordax) from the river, the beginning of capelin spawning, the presence of herring (Clupea harengus) and the onset of the adult salmon run. There have been reports by DFO research personnel of beaters chasing and consuming kelt salmon and seals have been observed chasing adult salmon near the river mouth (Table 2). All respondents considered increasingly light and variable ice conditions to be important factors in explaining the increase in seal numbers during the smolt run (Table 3). Two hunters remarked that prior to 1990 harp seals remained in more 
Table 3. Summary of Biological and Physical Characteristics that may Attract Seals to a River or have the Potential to Increase the Susceptibility of Migrating Salmon to Seal Predation During the Smolt or Adult Salmon Run

\begin{tabular}{|c|c|c|c|c|c|c|c|c|c|c|c|c|c|}
\hline \multirow[b]{2}{*}{ River } & \multirow[b]{2}{*}{ 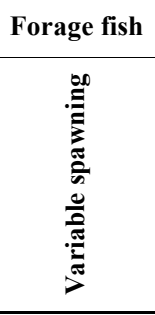 } & \multicolumn{3}{|c|}{ Proximity to } & \multicolumn{6}{|c|}{ River Characteristics } & \multicolumn{3}{|c|}{ Estuary Ice } \\
\hline & & 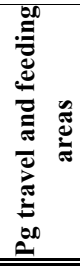 & 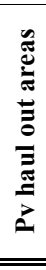 & 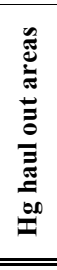 & 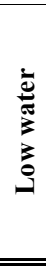 & לั & 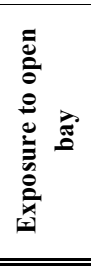 & 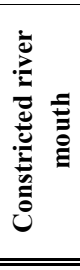 & 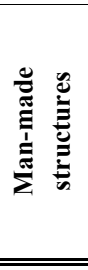 & 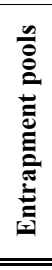 & 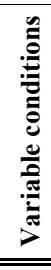 & 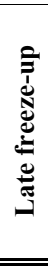 & 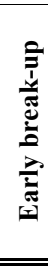 \\
\hline 1. North & + & + & + & + & & & + & & & & & & \\
\hline 2. White Bear & + & + & + & + & & & & & & + & + & + & + \\
\hline 3. Eagle & + & + & + & + & & & & & & + & + & + & + \\
\hline 4. Paradise & + & + & + & + & + & + & & & & & + & + & + \\
\hline 5. Sandhill & + & + & + & + & + & & & & & & & & \\
\hline 6. St. Lewis & + & + & & & & & & + & + & & + & & + \\
\hline 7. St. Mary’s & + & + & & & + & + & & + & + & & + & & + \\
\hline 8. St. Charles & + & + & & & & + & & & & & + & & + \\
\hline 9. Pinware & + & + & + & + & & & + & + & & & + & & \\
\hline 10. Forteau & + & + & & + & & & + & & & & + & & \\
\hline 11. Torrent & + & + & + & + & + & & & + & + & + & + & & \\
\hline 16. Flat Bay & & & + & & & & + & + & & & + & & + \\
\hline $\begin{array}{l}\text { 17-21. Fischells, } \\
\text { Robinson's, Barachois, }\end{array}$ & & & + & & + & + & + & + & & & + & & \\
\hline $\begin{array}{l}\text { 23-26. Rocky, Collinet, } \\
\text { NE Brook, NW Brook }\end{array}$ & & & + & & & & & & & & & & \\
\hline 27. Gander & + & + & & & + & + & & + & + & + & + & + & + \\
\hline 28. Campbellton & + & + & & & + & + & + & + & + & & + & + & + \\
\hline
\end{tabular}

offshore waters and rarely frequented Indian Arm Bay during the late winter and early spring because ice usually impeded access to the area. However in recent years, the timing of spring break up has shifted from late April to late March allowing young seals early access to the area.

Respondents interviewed at the Gander River noted an increase in the relative abundance and residency time of harp seals by the year 2000 (Table 1; Fig. 1: location 27). All respondents (6/6) have observed individual and small groups of seals hauled out on rocks near the mouth of the river and 4 $-5 \mathrm{~km}$ up the main stem throughout the smolt and adult salmon runs. Two respondents have observed seals feeding on adult salmon, while three have seen salmon with their stomach cavities ripped open and believe this could have been caused by a seal (Table 2). The identification of these species was not certain; however, based on the haul out behavior, it is likely they were a mixture of immature harp seals and harbor seals (Wayne Penney, personal communication). Unidentified seals were also sighted in Gander Lake, approximately $30 \mathrm{~km}$ from the river mouth. Similar to the situation at Campbellton River, 4/6 respondents noted that during the last decade, light and variable ice conditions have allowed seals access to Gander Bay throughout the winter and early spring (peak period December to February). Since 2000, an increased number of seals (1-35 at a time) have been frequenting an open water area created by a causeway at the river mouth; some of these seals remain in the area until the smolt and adult salmon run. Although there is no capelin in Gander Bay, smelt is present during the winter which overlaps with the residency of the seals.

Respondents noted no increase in the spatial or temporal overlap of harp seals and salmon on the Humber, Torrent and Lomand Rivers, rivers in St. George's Bay or rivers located in southern Newfoundland (Table 1).

\section{Observations on Other Seal Species}

Salmon rivers on the western and southern coasts of Newfoundland appeared to be more susceptible to potential harbor seal predation, while rivers in Sandwich Bay, Labrador were susceptible to both harbor and gray seal predation. Respondents noted that harbor seals were occasionally observed in rivers along the south and west coast of Newfoundland prior to 1990, but increased their 
presence at a number of rivers in the recent past and present time periods. The occurrence and relative abundance of gray seals frequenting St. Lewis Sound, the Pinware River, Forteau Brook and the Torrent River during the adult salmon run has increased in recent times (Table 1). Harbor and gray seals were observed more often than harp seals taking salmon from fishing nets or foraging at the river mouth.

\section{Harbor Seals}

Respondents (7/7) considered harbor seals to be the main potential seal predator on adult salmon entering rivers in Sandwich Bay. This species has historically been present near the Eagle, White Bear, and Paradise rivers during adult runs (Table 1). At the Paradise River, seals were observed migrating into the river in June, and leaving in November before fall and winter freeze-up. Estimates of local abundance ranged between 50-100 animals, with a steady increase in the number of seals being sighted during the 1990s. Respondents frequently observed harbor seals around salmon nets during the subsistence fishery. Seals were also sighted in Table Bay near the Sandhill Hill River; however, their distribution and relative abundance in this bay were not known. Respondents rarely observed harbor seals during smolt or adult salmon runs in St. Lewis Sound near the Pinware River or Forteau Brook. Respondents thought the low number of seals in St. Lewis Sound and surrounding area was due to heavy hunting pressure in the 1970s.

Harbor seals have historically been present in St. George's Bay, but respondents (9/10) felt the relative abundance of this species has increased over the past 15 years on 6/8 rivers (Table 1; Fig. 1: locations 16-21). Seals were most often observed at river mouths from March to June, but in recent years have started moving into some rivers. Flat Bay Brook appeared to have the highest potential for predation, but seals also frequented the Highlands, Crabbes, Fishchells, Robinsons and Southwest Brook rivers. At Flat Bay Brook, two respondents first observed seals in March when ice was still present in the estuary. Seals then moved upriver after the spring thaw, concurrent with the seaward migration of smolt from the river. Single seals and small sculls of 2-3 have been observed $1 \mathrm{~km}$ upriver and one respondent had observed seals chasing smolt in Flat Bay. Sculls of 2-10 harbor seals were also observed at river mouths on the Highlands and Crabbes Rivers during smolt and adult salmon runs. Respondents identified two main haul out sites, one near Flat Bay and the other south of Highlands River. Estimates of scull sizes for seals congregated at the site near Flat Bay Brook ranged from 5-40 animals; however most observations were of sculls with 5-15 seals. Estimates of relative abundance for the site near Highlands River ranged from 100-500 seals. This site is remote and only accessible by boat, therefore respondents did not know if seals occupied it all year round.

According to respondents, the relative abundance of harbor seals has increased in several bays on the southern coast of Newfoundland (Table 1; Fig. 1, locations 22-26). All respondents stated that harbor seal populations near Northeast and Northwest Brook Trepassey have steadily increased since 1990. A natural waterfall at Northeast Brook prevents seals from entering the main stem, but respondents occasionally observed seals at the river mouth and in the estuary during both the smolt and adult run. No respondents observed seals at the Collinet River, and only one respondent had observed seals at the mouth of the Rocky River during the adult run (a waterfall prevents seals from accessing the main stem of the river). Although seals are rarely seen at the Rocky and Collinet rivers, they utilize haul-out sites in the bay during the adult salmon run. Respondents commonly observed harbor seals hauled out on rocks approximately 9 $\mathrm{km}$ from both river mouths. Herring and capelin spawn in the estuary, but according to respondents, both species have decreased in abundance over the last 15 years, with variable or no spawning in some years.

\section{Gray Seals}

Gray seals were present on all rivers in southern Labrador, but were mainly observed during the adult salmon run on the White Bear, Eagle and Pinware rivers. According to respondents, their relative abundance in the Sandwich Bay area increased starting in the mid 1990s, and 4/7 respondents identified one haul-out area near the Eagle River. Although respondents had not observed gray seals in St. Lewis Sound until 2000, they were known to be present at St. Peter's Bay, approximately $20 \mathrm{~km}$ south of the Sound. The relative abundance of seals in St. Lewis appears to have increased since that time and $3 / 5$ respondents have occasionally observed gray seals at salmon nets during the local subsistence fishery. Some of the respondents from the Pinware, Forteau and Torrent rivers considered gray seals to be the 'new' population of seals because they had never observed them before. At the Pinware River, gray seals were rarely observed during the 1990s but according to respondents $(5 / 5)$ their relative abundance increased starting in 2000. Seals were observed hauled out on two islands and a sandbar near the river mouth during the adult run. Capelin and herring also spawn in the vicinity of the river mouth. Gray seals were never observed at the Torrent River before 1995 , but $4 / 4$ respondents indicated their relative abundance increased in the late $1990 \mathrm{~s}$ and continued to increase through the present time period. One haul-out site was identified along the headlands near the Torrent River where seals congregate from late summer until October. None of the respondents observed seals at the mouth of the Torrent River and no direct interactions were observed.

\section{DISCUSSION}

Local ecological knowledge collected from interviews with resource users suggests an increase in the spatial and temporal overlap of seals and salmon on a number of rivers in Newfoundland and southern Labrador. Changes in the distribution and extended occupation of harp seals in nearshore waters also suggest that the potential for harp seal predation on salmon has increased since the mid-to late 1990s. Although harbor and gray seals have historically been present at certain salmon rivers, an increased relative abundance of these species over approximately the same time period suggests increased predation potential by them as well. Based on these observations, eight rivers frequented by harp seals, nine by harbor seals, and three by gray seals were categorized as having a high potential for predation (Table 4). Variation in potential predation from river to river can be partially explained by geography, the ecology of seal species frequenting the area, and migratory behavior of the 
Table 4. Summary of Rivers Evaluated as Having a High Potential for Seal Predation During the Smolt or Adult Run in 2000-2005 Based on the Relative Occurrence of Seals, Biological and Physical Characteristics of the River and/or Nearshore Habitat and the Occurrence of Direct or Indirect Seal-Salmon Interactions. Refer to Fig (1) for Location of Rivers

\begin{tabular}{|c|c|c|c|}
\hline \multirow[b]{2}{*}{ River } & \multirow[b]{2}{*}{ Key Observations for Evaluation } & \multicolumn{2}{|c|}{ High Potential } \\
\hline & & Smolt & Adult \\
\hline 2-3. White Bear, Eagle & $\begin{array}{l}\text { Harp seals commonly observed along headlands of Sandwich Bay during adult migrations; } \\
\text { presence of capelin; indirect interactions. Harbor and gray seals commonly observed } \\
\text { during adult migrations; waterfall impedes salmon at river mouth; direct and indirect } \\
\text { interactions. }\end{array}$ & $\mathrm{Pv}$ & $\mathrm{Pg}, \mathrm{Pv}, \mathrm{Hg}$ \\
\hline 4. Paradise & $\begin{array}{l}\text { Harp seals commonly observed along headlands of Sandwich Bay during adult migrations; } \\
\text { presence of capelin; indirect interactions. Harbor and gray seals commonly observed } \\
\text { during smolt and adult migrations; haul-out and pupping locations in river; direct and } \\
\text { indirect interactions. }\end{array}$ & $\mathrm{Pv}$ & $\mathrm{Pg}, \mathrm{Pv}, \mathrm{Hg}$ \\
\hline 6. St. Lewis & $\begin{array}{l}\text { Harp seals commonly observed during adult migrations; presence of capelin; indirect } \\
\text { interactions. }\end{array}$ & & $\mathrm{Pg}$ \\
\hline 7. St. Mary's & $\begin{array}{l}\text { Harp seals commonly observed during adult migrations; presence of capelin; indirect } \\
\text { interactions. }\end{array}$ & & $\mathrm{Pg}$ \\
\hline 8. St. Charles & $\begin{array}{l}\text { Harp seals commonly observed during adult migrations; presence of capelin; indirect } \\
\text { interactions. }\end{array}$ & & $\mathrm{Pg}$ \\
\hline $\begin{array}{l}17 \text {-21. Flat Bay, Fischells, } \\
\text { Robinson's, Barachois, } \\
\text { Crabbes, Highlands }\end{array}$ & $\begin{array}{l}\text { Harbor seals commonly observed during smolt and adult migrations; constricted river } \\
\text { mouths exposed to coastline; haul-out sites close to river; seals observed chasing salmon. }\end{array}$ & $\mathrm{Pv}$ & $\mathrm{Pv}$ \\
\hline 27. Gander & $\begin{array}{l}\text { Harp seals commonly observed during smolt run; variable spring ice conditions and winter } \\
\text { thaws allowing seals early access to nearshore habitats; open water near river mouth; seals } \\
\text { observed chasing salmon and salmon with claw marks; presence of smelt. }\end{array}$ & $\mathrm{Pg}$ & \\
\hline 28. Campbellton & $\begin{array}{l}\text { Harp seals commonly observed during smolt run; variable spring ice conditions allowing } \\
\text { seals earlier access to nearshore habitats; presence of capelin, smelt and some herring; } \\
\text { seals observed feeding on salmon. }\end{array}$ & $\mathrm{Pg}$ & \\
\hline
\end{tabular}

predator and prey. Salmon rivers located on relatively exposed coastlines adjacent to late spring feeding areas and migration routes for harp seals appear more susceptible to seal-salmon interactions. Those located in well protected inland bays or those located to the south of habitats traditionally used by harp seals in the late spring and summer were frequented more often by harbor or gray seals that had permanent or summer haul-out sites near the river mouth. Changes in the seasonal distribution and delayed spawning times of forage fish, particularly capelin, also appears to be an important factor in determining which rivers harp sealsalmon interactions occurred. In the recent past, ice conditions in some bays have become increasingly variable, and in some cases lighter. This has allowed harp seals access to coastal habitats that were previously protected by ice during their spring migration. For some areas, early access by seals was associated with extended residency time and increased spatial and temporal overlap with smolt runs.

There are limitations when interpreting LEK spanning a long time period including fragmentary information due to loss of memory, variation in the comprehensiveness or quality of data collected due to the experience of the respondent [38, 41] and identifying incorrect or biased information [37, 42]. More specific to this study, resource users often dislike seals because they consider them competitors for limited fish resources and this view may bias their response to questions. These potential biases were minimized in several ways. We interviewed three or more respondents for each river or group of rivers; there were few instances where data discrepancies among respondents could not be resolved. Interviews were conducted face-to-face, a technique which can provide more reliable information compared to telephone interviews or written questionnaires [42]. Approximately $50 \%$ of the respondents were called back to confirm information and there was no evidence of significant inconsistencies. Whenever possible, LEK data were corroborated with available data in the literature and DFO researchers who had experience working in the area (particularly regarding seal species identification). Additionally, it should be noted that the focus of the LEK approach was not to directly ask resource users their opinion on the importance of seal predation on salmon, but rather to collect ecological information from them that would allow us to objectively evaluate potential seal predation.

Local ecological knowledge of historic harp seal migration patterns and general habitat use was consistent with published information [27, 43, 44]. This was particularly the case for respondents living in communities along the northeast and northwest coasts of Newfoundland and southern Labrador. Information on changes in the timing of seasonal migrations, the use of coastal habitat during the spring and summer, and increasing relative abundance of 
seals in coastal waters, provides a complementary perspective to several studies documenting shifts in harp seal seasonal distribution and movement patterns in more offshore areas during the 1990s. Starting in 1994 there was a general increase in the occurrence of harp seals sighted during the summer near Sable Island, Nova Scotia [45] and most notably, along the eastern seaboard of the United States [20, 46, 47]. Lacoste and Stenson [21] also reported that, based on sighting data, the winter distribution of harp seals off Newfoundland also moved southward in 1994 and 1995. Satellite tagging in the mid 1990s $(n=22$ seals $)$ also indicated anomalies in the distribution and movement patterns of seals including decreased use of the northern portion of the Arctic summer feeding range and/or increased use of southern Grand Banks wintering range [48].

Shore-based spawning studies and fisherman logbook programs conducted during the early to mid 1990s provided evidence of changes in the reproductive biology of capelin consistent with cool oceanographic conditions in many areas of the province $[18,24]$. LEK on the changes in spawning times, seasonal migration patterns and changing use of beach and demersal spawning habitat is consistent with the shorebased and logbook programs. Unfortunately, because these programs are limited to relatively few sites around the Province, our understanding of finer scale changes in capelin spawning ecology is fragmented. LEK on capelin spawning behavior collected in this study provided new information for areas where there has been limited capelin research effort.

In contrast to the detailed LEK available on capelin, none of the respondents interviewed were able to comment on the occurrence, distribution, or changes in the relative abundance of Arctic cod in their areas during the study period. This data gap should be addressed in any future LEK research pertaining to the spatiotemporal overlap of harp seals and salmon in nearshore habitats. Given the predominance of Arctic cod in the diet of harp seals during the 1990s [26] a major change in its distribution was likely important for harp seals. The resource users interviewed may not have been familiar with Arctic cod since it has never been commercially fished and therefore may have been mistakenly identified as immature Atlantic cod. This explanation has merit given the many reports DFO personnel received from fishermen concerned about the large amounts of young Atlantic cod found in the stomachs of harp seals killed in nearshore waters during the mid to late 1990s. When samples were obtained for species identification, virtually all were Arctic $\operatorname{cod}^{2}$. In addition, Arctic cod abundance was remarkably high in nearshore Newfoundland waters for only a relatively short period of time (1990-1997) and it dropped when ocean temperatures warmed and fish distributions shifted north [49]. Most respondents probably had limited exposure to the species.

In some locations, it appears that the presence of capelin coupled with delayed spawning behavior are potential contributing factors in attracting harp seals into nearshore habitats for longer periods of time. There is some evidence in the literature to support this interpretation. The southward shift in distribution of both capelin $[19,24]$ and harp seals
[20, 21, 46] during the mid 1990s suggests a predator-prey relationship between these species. However, it is interesting to note that two salmon rivers, the Pinware and Forteau Brook on the south coast of Labrador, had capelin (and herring) spawning on their respective beaches, yet neither river was frequented by harp seals during salmon migrations. There were no conclusive explanations from the information provided by the respondents as to the reason why harp seals passed by these rivers. The presence and activity of harbor and gray seals at salmon rivers did not appear to be strongly linked with delayed capelin spawning activity. The location of haul-out sites and presence of salmon nets appeared to be more important factors.

Resource users were also able to provide a considerable amount of new information regarding the relative abundance and distribution of harbor and gray seals during salmon runs. LEK on the general distribution of harbor seals is supported by the early research of Boulva and McLaren [28]. Evidence of increasing relative abundance in some rivers and bays is corroborated by similar findings based on DFO boat surveys of several known harbor seal haul-out sites on the south and northwest coasts of the Province [9]. Gray seals frequent Newfoundland and Labrador coastal waters in low numbers primarily during the summer [50]; however, there is only limited information on their distribution and relative abundance in nearshore waters or rivers in the Province. Evidence of increased abundances at some rivers and establishment of new haul-out sites near other rivers is consistent with the rapid growth of gray seal populations and distributions on the Scotian Shelf [51] and in the Gulf of St. Lawrence [30, 31]. Relatively little research has been conducted on these species in Newfoundland and Labrador waters, and LEK was an effective way to document the movements of these seal species into new areas of the province, map the locations of seasonal haul-out sites, identify possible pupping locations and monitor the occurrence of seal-salmon interactions.

The most important physical habitat characteristics identified by respondents that could affect the susceptibility of salmon to potential predation by seals were variable or light coastal ice conditions, man-made or natural features that caused salmon to aggregate in rivers, and low water levels. On two rivers, changes in local ice conditions due to warmer winters in recent years allowed harp seals increased and earlier access to nearshore areas that were previously protected by ice. Harp seals are well adapted to drifting pack ice in offshore areas, but they are unable to maintain breathing holes in stable coastal ice [27]. Structures such as bridges and causeways that create or maintain open water areas can attract and allow seals to remain in these areas for most of the winter and gain early access in the spring. In the case of harbor seals that spend most of their life near or onshore close to river mouths, winter ice restricts their movements to shoreline cracks or to the nearest open water outside the estuary [28]. Warmer winters and variable coastal ice cover allows all seals greater access to coastal habitats. Based on the findings of this study, LEK may be a practical approach for monitoring changes in ice conditions when early access by seals could increase the potential for predation on smolt later in the spring.

${ }^{2}$ (Dave Mckinnon, personal communication, 2007). 
In St. George's Bay, six of the rivers are clustered within a short proximity, and all have relatively constricted river mouths exposed directly to the bay. These physical features may allow harbor seals to focus their activity at the river mouth where migrating salmon are funneled through. On both the White Bear and Eagle rivers in southern Labrador, there is a waterfall that often delays the migration of adult salmon, which can make them more susceptible to predation by all seal species as well as other predators. Low water levels in combination with warm water temperatures can also exacerbate the effects of these types of habitat features by further restricting the movements of salmon and inducing thermal stress [52]. Rivers with these habitat features and that are prone to low water levels represent potential areas for increased seal predation and require further study. LEK collected to date will provide direction for this research and also contribute to the development of river-specific salmon management plans.

In summary, local ecological knowledge was used to evaluate potential predation by seals on salmon in rivers and nearshore waters over a 25 -year period. The degree of potential predation was based on the occurrence and relative abundance of seals in river and nearshore habitats, direct and indirect seal-salmon interactions, and the presence of ecological or physical habitat characteristic that could increase the susceptibility of salmon to predation. This knowledge provided a useful and, in many cases, new perspective on the spatial and temporal overlap of seals (particularly harp seals), salmon, and forage fish at some rivers in Newfoundland and southern Labrador. However, assessing potential predation was based on people's observations of multiple species co-occurrence in a river or nearshore habitat. Quantitative seal diet information and knowledge of seal-salmon relative abundances on a riverspecific basis are required to assess the biological significance of these results from a salmon conservation perspective.

\section{ACKNOWLEDGEMENTS}

We are especially grateful to all of the resource users who participated in this project and shared their knowledge and experiences with us. Special thanks go to Gilb Budgell, Calvin Frances, Wayne Penney and Peter Downton for their support and expertise in the field. Dave Mckinnon, Dennis Wakeham and Jack Lawson provided valuable assistance in the lab. We would like to thank Larry Felt and Barbara Neis for assistance in designing the interview protocol. Ted Miller provided guidance throughout the project as well as thoughtful comments on an earlier version of the manuscript. We also thank David Cairns, Garry Stenson, Geoff Veinott and two anonymous reviewers for their valuable comments on the manuscript. This project was funded by a grant to Becky Sjare from Natural Resources Canada: Climate Change Impacts and Adaptations Fund.

\section{REFERENCES}

[1] Brice-Bennet C. In: Brice-Bennet C, Ed. Our footprints are everywhere: Inuit land use and occupancy in Labrador. Nain: Labrador Inuit Association. 1977; pp. 97-203.

[2] Taylor VR. The early Atlantic salmon fishery in Newfoundland and Labrador. Can Spec Publ Fisheries Aquat Sci 1985; 76.

[3] Dempson JB, O'Connell MF, Schwarz CJ. Spatial and temporal trends in abundance of Atlantic salmon, Salmo salar, in
Newfoundland with emphasis on impacts of the 1992 closure of the commercial fishery. Fisheries Manag Ecol 2004; 11: 387-402.

[4] Cairns DK. An evaluation of possible causes of the decline in prefishery abundance of North American Atlantic salmon. Canadian Technical Report of Fisheries and Aquatic Science 2001; No. 2358.

[5] Lawson JW, Stenson GB. In: Blix AS, Ulltang Ø, Walloe L, Eds. Seals, whales, fish and man. Tromsø, Elsevier Science 1995; pp. 261-69.

[6] Lawson JW, Stenson GB. Diet of northwest Atlantic harp seals (Phoca groenlandica) in offshore areas. Can J Zool 1997; 75: 2095-106.

[7] Stenson GB, Perry EA. Incorporating uncertainty into estimates of Atlantic cod (Gadus morhua), capelin (Mallotus villosus) and Arctic cod (Boreogadus saida) by harp seals (Pagophilus groenlandicus) in NAFO divisions 2J3KL. DFO Canadian Science Advisory Secretariat Research Document 2001/074; [cited 2008 December 17]. Available from: www.dfo-mpo.gc.ca/csas/

[8] Middlemas SJ, Barton TR, Armstrong JD, Thomspon PM. Functional and aggregative responses of harbour seals to changes in salmonid abundance. Proc R Soc B 2006; 273: 193-8.

[9] Sjare B, LeBeuf M, Veinott G. Harbor seals in Newfoundland and Labrador: a preliminary summary of new data on aspects of biology, ecology and contaminant profiles. DFO Canadian Science Advisory Secretariat Research Document 2005/030; [cited 2007 December 10]. Available from: www.dfo-mpo.gc.ca/csas/

[10] Cairns DK, Reddin DG. The potential impact of seal and seabird predation on North American Atlantic salmon. Canadian Stock Assessment Secretariat Research Document 2000/12; [cited 2010 July 1]. Available from: www.dfo-mpo.gc.ca/csas

[11] Hammill MO, Stenson GB, Proust E, Carter P, McKinnon D. Feeding by gray seals in the Gulf of St. Lawrence and around Newfoundland. NAMMCO Scientific Publications 2007; 6: 13552.

[12] Brown RF, Mate BR. Abundance, movements and feeding habits of harbor seals, Phoca vitulina, at Netarts and Tillamook bays, Oregon. Fish Bull 1983; 81: 291-301.

[13] Olesiuk, P. Annual prey consumption by harbor seals (Phoca vitulina) in the Strait of Georgia, British Columbia. Fish Bull 1993; 91: 491-515.

[14] Orr AJ, Banks AS, Mellman S, Huber HR, Delong RL, Brown RF. Examination of the foraging habits of pacific harbor seal (Phoca vitulina richardsi) to describe their use of the Umpqua River, Oregon, and their predation on salmonids. Fish Bull 2004; 102: 108-17.

[15] Carter TJ, Pierce GJ, Hislop JRG, Houseman JA, Boyle PR. Predation by seals on salmonids in two Scottish estuaries. Fisheries Manag Ecol 2001; 8: 207-25.

[16] Colbourne E, Narayannan S, Prinsenberg S. Climate changes and environmental conditions in the northwest Atlantic, 1970-1993. ICES Mar SC 1994; 198: 311-22.

[17] Drinkwater KF. Atmospheric and oceanic variability in the northwest Atlantic during the 1980 s and early 1990s. J Northwest Atl Fish Sci; 1996; 18: 77-97.

[18] Carscadden JE, Frank KT, Leggett WC. Ecosystem changes and the effects on capelin (Mallotus villosus), a major forage species. Can J Fish Aquat Sci 2001; 58: 73-85.

[19] Frank KT, Carscadden JE, Simon JE. Recent excursions of capelin (Mallotus villosus) to the Scotian Shelf and Flemish cap during anomalous hydrographic conditions. Can J Fish Aquat Sci 1996; 53: $1473-86$

[20] McAlpine DF, Stevick PT, Murison LD. Increase in extralimital occurrences of ice-breeding seals in the northern Gulf of Maine region: More seals or fewer fish? Mar Mammal Sci 1999; 15: 90611.

[21] Lacoste KN, Stenson GB. Winter distribution of harp seals (Phoca groenlandica) off eastern Newfoundland and southern Labrador. Polar Biol 2000; 23: 805-11.

[22] Parsons LS, Lear WH. Climate variability and marine ecosystem impacts: a North Atlantic perspective. Prog Oceanogr 2001; 49: 1167-88.

[23] Lawson JW, Anderson JT, Dalley EL, Stenson GB. Selective foraging by harp seals, Phoca groenlandica, in nearshore and offshore waters of Newfoundland, 1993 and 1994. Mar Ecol-Prog Ser 1998; 163: 1-10.

[24] Carscadden JE, Nakashima BS. Abundance and changes in distribution, biology and behavior of capelin in response to cooler 
waters of the 1990s. Proceedings of the International Symposium on the Role of Forage Fishes in Marine Ecosystems: Fairbanks, Alaska: Alaska Sea Grant College Program 1997; pp. 457-68.

[25] Lilly GR, Hop H, Stansbury DE, Bishop CA. Distribution and abundance of polar cod (Boreogadus saida) off southern Labrador and eastern Newfoundland. ICES document CM 1994/O:6.

[26] Lawson JW, Stenson GB, McKinnon DG. Diet of harp seals (Phoca groenlandica) in nearshore waters of the northwest Atlantic during 1990-1993. Can J Zool 1995; 73: 1805-18.

[27] Sergeant, DE. Harp seals, man and ice. Can Spec Publ Fisheries Aquat Sci 1991; No. 114.

[28] Boulva J, McLaren, IA. Biology of the harbor seal, Phoca vitulina, in eastern Canada. Bull Fish Res Board Can 1979; No. 200.

[29] Mansfield AW, Beck B. The gray seal in eastern Canada. Fisheries and Marine Service Technical Report, No. 704, 1977.

[30] Hammill MO, Stenson GB, Myers RA, Stobo WT. Pup production and population trends of the gray seal (Halichoerus grypus) in the Gulf of St. Lawrence. Can J Fish Aquat Sci 1998; 55: 423-30.

[31] Hammil MO, Gosselin, JF, Stenson GB. Abundance of Northwest Atlantic gray seals in Canadian waters. NAMMCO Sci Publ 2007; 6: 99-115.

[32] Drinkwater KF. Atmospheric and sea-ice conditions in the northwest Atlantic during the decade, 1991-2000. J Northwest Atl Fish Sci 2004; 34: 1-11.

[33] Dempson, JB, O'Connell MF, Reddin DG, Cochrane NM. Stock status summary for Atlantic salmon in Newfoundland and Labrador. DFO Canadian Science Advisory Secretariat Research Document 2006/028; [cited 2008 December 17]. Available from: www.dfo-mpo.gc.ca/csas/

[34] Neis B, Felt L, Haedrich RL, Schneider DC. In Newell D, Omer R, Eds. Fishing places, fishing people: issues and traditions in Canadian small-scale fisheries. Toronto, University of Toronto Press 1999; pp. 217-38.

[35] Huntington HP. Using traditional ecological knowledge in science: methods and applications. Ecol Appl 2000; 10: 1270-4.

[36] Mallory ML, Gilchrist HG, Fontaine AJ, Akearok JA. Local ecological knowledge of ivory gull declines in Arctic Canada. Arctic 2003; 56: 293-8.

[37] Ferguson MA, Messier F. Collection and analysis of traditional ecological knowledge about a population of Arctic tundra caribou. Arctic 1997; 50: 17-28.

[38] Neis B, Felt L, Haedrich RL, Fischer J, Hutchings JA. Fisheries assessment: What can be learned from interviewing resource users? Can J Fish Aquat Sci 1999; 56: 1949-63.
[39] Usher PJ. Traditional ecological knowledge in environmental assessment and management. Arctic 2000; 53: 183-93.

[40] Huntington HP. Observations on the utility of the semi-directive interview for documenting traditional ecological knowledge. Arctic 1998; 51: 237-42.

[41] Davis A, Wagner JR. Who knows? On the importance of identifying "experts" when researching local ecological knowledge. Hum Ecol 2003; 31: 463-89.

[42] Lein J, Stenson GB, Carver S, Chardine J. In: Perrin WF, Donovan GP, Barlow J, Eds. Reports of the International Whaling Commission 15 (special issue). Cambridge 1994; pp. 535-40.

[43] Sergeant DE. Migration of harp seals, Pagophilus groenlandicus Erxleben, in the northwest Atlantic. J Fish Res Board Can 1965; 22: 433-64

[44] Stenson GB, Kavanagh DJ. Distribution of harp and hooded seals in offshore waters of Newfoundland. NAFO Sci Coun Studies 1993; 21: 121-42.

[45] Lucas Z, Daoust P. Large increases of harp seals (Phoca groenlandica) and hooded seals (Cystophora cristata) on Sable Island, Nova Scotia, since 1995. Polar Biol 2002; 25: 562-8.

[46] Stevick PT, Fernald TW. Increase in extralimital records of harp seals in Maine. Northeast Nat 1998; 5: 75-82.

[47] Harris DE, Lelli B, Jakush G. Harp seal records from the southern Gulf of Maine: 1997-2001. Northeast Nat 2002; 9: 331-40.

[48] Stenson GB, Sjare B. Seasonal distribution of harp seals, Phoca groenlandica, in the northwest Atlantic. ICES document CM 1997/CC:10.

[49] Lilly GR, Simpson M. Distribution of capelin, Arctic cod and sand lance on the Northeast Newfoundland Shelf and Grand Bank as deduced from bottom-trawl surveys. DFO Canadian Stock Assessment Secretariat Research Document 200/091; [cited 2008 December 17]. Available from: www.dfo-mpo.gc.ca/csas/

[50] Mansfield AW. Seals of Arctic and eastern Canada. Fisheries Res Board Can Bull 1967; no 137.

[51] Bowen WD, McMillan J, Mohn R. Sustained exponential population growth of gray seals at Sable Island, Nova Scotia. ICES J Mar Sci 2003; 60: 1265-74.

[52] Dempson JB, O'Connell MF, Cochrane NMR. Potential impact of climate warming on recreational fishing opportunities for Atlantic salmon, Salmo salar, in Newfoundland, Canada. Fisheries Manag Ecol 2001; 8: 69-82.

(c) Lenky and Sjare; Licensee Bentham Open.

This is an open access article licensed under the terms of the Creative Commons Attribution Non-Commercial License (http://creativecommons.org/licenses/by-nc/3.0/) which permits unrestricted, non-commercial use, distribution and reproduction in any medium, provided the work is properly cited. 